\title{
DISCRIMINATION ON THE GROUNDS OF PREGNANCY, DENIAL OF MATERNITY LEAVE AND LACK OF CONDUCIVE ENVIRONMENT FOR NURSING MOTHER IN THE WORKPLACE IN SOUTH AFRICA
}

\author{
Motlhatlego D Matotoka
}

LLB LLM

Doctoral Candidate, School of Law

University of Limpopo

Kola O Odeku

LLB LLM MBA LLD

Professor, Faculty of Law, University of Limpopo

SUMMARY

In South Africa, women continue to be discriminated against on the grounds of being pregnant in the workplace and sometimes they are denied maternity leave, breastfeeding and childcare facilities. Methodologically, using a descriptive and content analysis research approach, this article examines how the apartheid era restricted the rights of pregnant women in the workplace, particularly black African women. Post-1994 South Africa, the article utilised various protective transformative legal and policy interventions that have been introduced and are being implemented to address the problem of discrimination against women on the grounds of pregnancy in the workplace.

Discrimination on the grounds of pregnancy exhibits a coherent social logic. ${ }^{1}$ What is worrisome is that women are being excluded from employment on the basis of pregnancy and this perpetuates the sexual division of productive

Gueutal, Luciano and Michaels "Pregnancy in the Workplace: Does Pregnancy Affect Performance Appraisal Ratings?" 1995 Journal of Business and Psychology 155-167. 
and reproductive labour which confirms women's second-class status in the workplace. ${ }^{2}$

Undoubtedly, in South Africa, patriarchal attributes viewed women as inferior beings to males and consequently not entitled to work. ${ }^{3}$ Since the $20^{\text {th }}$ century in South Africa women were subjected to discrimination and black African women in particular were subject to a triple oppression in terms of their race, gender and class. Due to patriarchal attitudes, black African women were largely employed as caregivers and restricted to household activities, procreation roles and maintaining of households. ${ }^{4}$ In terms of race, black African women were inferior beings and in terms of class, they were excluded from education and employment opportunities. ${ }^{5}$ This resulted in most black African women being confined to inferior job opportunities primarily in the informal sector. Women who were able to access job opportunities in the formal sector, were subjected to various discriminations such as unfavourable working conditions and unfair labour practice when they became pregnant. ${ }^{6}$ During apartheid, interruption of service by pregnancy did not guarantee re-employment after birth. ${ }^{7}$ Essentially black African female employees who were pregnant were likely not to be reemployed. $^{8}$ The apartheid period in South Africa denied black African women of significant employment rights and ultimately active participation in the South African economy.

The discrimination of black African women was exacerbated in the factory jobs during late $1978 .{ }^{10}$ The Black Sash, a non-violent liberal white women's resistance organisation in South Africa unearthed that during this period women were paid less in factories, employment was terminated if women became pregnant and no pension or provident funds were provided for women notwithstanding the physical, emotional and time-intensive work allocated to them. ${ }^{11}$ The exploitation of women in the workplace was

2 Siegel "Employment Equality Under the Pregnancy Discrimination Act of 1978" 1985 Yale Law Journal 929-930. See also Jones "To Tell or Not to Tell? Examining the Role of Discrimination in the Pregnancy Disclosure Process at Work" 2017 Journal of Occupational Health Psychology 239-240.

3 Langa Becoming a Man: Exploring Multiple Voices of Masculinity Amongst a Group of Young Adolescent Boys in Alexandra Township, South Africa (report for the Degree of Doctor of Philosophy, Faculty of Humanities, University of Witwatersrand) 2012 2-7.

$4 \quad$ Nolde "South African Women Under Apartheid: Employment Rights, with Particular Focus on Domestic Service and Forms of Resistance to Promote Change" 1991 Third World Legal Studies 211-212.

5 Nolde 1991 Third World Legal Studies 211.

6 Salane Is There a Need for Black Feminism in South Africa? An Exploration into Systematic and Intersectional Exclusion (doctoral/master thesis, University of Johannesburg) 2018 4-17.

7 Black Sash Survey on Black Women in Employment in a Number of Pinetown Factories Paper presented at the Black Sash National Conference (14 March 1978) 1-5 www.sahistory.org.za (accessed 2018-03-21).

$8 \quad$ Black Sash paper presented at the Black Sash National Conference.

9 Gaitskell, Kimble and Maconachie "Class, Race and Gender: Domestic Workers in South Africa" 1983 Journal Review of African Political Economy 27-28.

10 South African History Online "Women, Employment and Changing Economic Scene, 1920s" www.sahistory.org.za/womens-struggle-1900-1994/women-employment-and-changingeconomic-scene-1920s (accessed 2018-09-16) 1-4.

11 Black Sash paper presented at the Black Sash National Conference 1-5. 
prevalent particularly because they were targets of even more oppression because of the lack of rights to be employed. ${ }^{12}$ Chapman asserts that the lack of rights of women in the workplace resulted in senior male managers abusing female employees by soliciting sexual favours in exchange for women keeping their jobs. ${ }^{13}$ This suggests that the employment of women was not dependent on the competency of the female employees but rather on the sexual favours rendered to those in the authority of the company. In order to address gender inequality, the discrimination and exploitation of women in the workplace, trade unions such as Garment Workers Union that resisted gender inequality and social injustice were formed to champion and demand equal treatment for all workers.

Meer points out that the Institute for Black Research unearthed that during the 1980s women were given odd jobs and management refused them time to see doctors when they were sick. ${ }^{15}$ Most women did not have medical aid schemes or pension funds. During these periods, women had no job security and were barred from having conversations during working hours and were restricted with time when going to the restrooms. Moreover, maternity and sick leave to pregnant women were not adequate and subject to many formalities that required proof. Promotions for women were few and far between, firing and retrenchment was a cause of constant anxiety. ${ }^{16}$ Black women had limited rights and choices both in society and in the workplace and this resulted in African women not only penalised due to race, but discriminatory practices allowed their exploitation in the workplace.

According to Lues, South Africa has an undoubtful history of discrimination in terms of gender and race which was perpetuated in both the public and private sector. ${ }^{17}$ However, post 1994, when South Africa became a democratic country, there was commitment to abolish discriminatory laws and commit to the values of equality including ubuntu. Ubuntu is an emerging value and a valuable transformative tool in the South African law that engenders African values to South Africa's legal culture. ${ }^{18}$ According to Himonga ${ }^{19}$ ubuntu promotes inclusivity and shared values and is key in the development of plural legal culture. It was anticipated that post1994 South Africa would enact and implement legislation that sought to

12 Barnett "Invisible Southern Black Women Leaders in the Civil Rights Movement: The Triple Constraints of Gender, Race, and Class" 1993 Gender \& Society 1-7.

13 Chapman "Women's Workplace Oppression in 1970s South Africa" South African History Online (2015) https://www.sahistory.org.za/article/women\%E2\%80\%99s-workplaceoppression-1970s-south-africa-cait-chapman (accessed 2018-09-16) 1-4.

14 Chapman https://www.sahistory.org.za/article/women\%E2\%80\%99s-workplace-oppression1970s-south-africa-cait-chapman 1-4.

15 Meer "Women in Apartheid Society" (2011) https://www.sahistory.org.za/archive/womenapartheid-society-fatima-meer-0 (accessed 2018-09-16) 1-12.

16 Meer https://www.sahistory.org.za/archive/women-apartheid-society-fatima-meer-0 1-12.

17 Lues "The History of Professional African Women: A South African Perspective" 2005 Interim: Interdisciplinary Journal 103-104.

18 Himonga "The Right to Health in an African Cultural Context: The Role of Ubuntu in the Realization of the Right to Health with Special Reference to South Africa" 2013 Journal of African Law 165-166.

19 Himonga 2013 Journal of African Law 167. 
equally protect the rights of black women, particularly in the workplace. ${ }^{20}$ It is against this backdrop that the Constitution of South Africa, 1996 (the Constitution) guaranteed the right to dignity, equality, right to fair labour practice to all persons irrespective of their position in life, more particular their gender. ${ }^{21}$ In principle, South Africa has significant laws to support the empowerment of women, promote gender equality and bar oppression and all forms of discrimination in the workplace. ${ }^{22}$

South Africa enacted the Employment Equity Act 55 of 1998 (EEA) with the aim to redress the embedded historical differentiation against black African women in the workplace. With the enactment of the EEA in 1998, it was anticipated that workplaces would transform and be inclusive to the extent that women would enjoy equal rights and benefits like their male counterparts in the workplace. ${ }^{23}$ The transformation of the workplace is informed by section 15(1) of the EEA that requires designated employers to implement affirmative action measures to ensure that previously disadvantaged groups such as women are equitably represented in all occupational levels in the workforce. $^{24}$ Section $15(4)$ of the EEA bars designated employers to take any decision regarding an employment policy or practice that would establish an absolute barrier to prospective or continued employment or advancement of people not from designated groups. $^{25}$

In view of past discriminatory practices against women in the workplace, South Africa further signed into law the Labour Relations Act 66 of 1995 (LRA) in 1995. The LRA reaffirms women's rights not to be dismissed in the workplace based on pregnancy. Section 187 of the LRA provides that a dismissal is automatically unfair if the employee is dismissed because of her pregnancy, intended pregnancy or a reason related to her pregnancy. ${ }^{26}$ As such, an employee who is dismissed on the grounds of pregnancy may invoke section 193(4) of the LRA, which states that a dismissal that is found to be automatically unfair can attract an order of reinstatement, reemployment or compensation. Section 187 of the LRA reaffirms the rights of women to be pregnant in the workplace and retain their jobs notwithstanding pregnancy. Section 187 of the LRA may, therefore, serve as a protective shield against employers who discriminate against pregnant employees in the workplace.

South Africa further signed into law the Basic Conditions of Employment Act 75 of 1997 (BCEA) in 1997 to enforce basic conditions of employment in

20 Grosser and Moon "Gender Mainstreaming and Corporate Social Responsibility: Reporting Workplace Issues" 2005 Journal of Business Ethics 327-328.

21 Wing and De Carvalho "Black South African Women: Toward Equal Rights" 1995 Harvard Human Rights Journal 57.

22 Romany "Black Women and Gender Equality in a New South Africa: Human Rights Law and the Intersection of Race and Gender" 1996 Brook Journal of International Law 857.

23 Dupper "In Defence of Affirmative Action in South Africa" 2004 South African Law Journal 187.

24 Dupper "Affirmative Action and Substantive Equality: The South African Experience" 2002 South African Mercantile Law Journal 275.

$25 \mathrm{~S} 15(4)$ of the EEA.

26 Whitear-Nel and Grant "Protecting the Unwed Woman against Automatically Unfair Dismissals for Reasons Relating to Pregnancy" 2015 Industrial Law Journal 106. 
the workplace. Of importance is section 25 of the BCEA which provides for four consecutive month's maternity leave. Section 26 of the BCEA prohibits employers from providing a pregnant employee or an employee who is nursing her child to perform work that is hazardous to her health or health of her child. Non-compliance with the BCEA could lead to penalties or compensation being awarded. ${ }^{27}$ Similar to the LRA, the BCEA reaffirms the protection of pregnant females in the workplace by providing equal rights to men, and further protection in terms of vulnerable female employees who are pregnant. ${ }^{28}$

Maternity leave is mostly unpaid in South Africa and this is because employers including the private sector companies are not obliged to provide paid maternity leave. ${ }^{29}$ It is submitted that in the private sector female employees are largely not to enjoy maternity leave benefits if the employer has not registered pregnant employees with the Department of Labour to claim maternity benefits in terms of section 24 of Unemployment Insurance Act 63 of 2001 (UIA). ${ }^{30}$ It is submitted that paid maternity leave serves as an attractive benefit for women to be employed and retained in the private sector. ${ }^{31}$ It is espoused that the retention of black African women in the workplace creates room for the employers to develop a pool of potential females to be given opportunity and an enabling environment to work in the workplace environments. ${ }^{32}$ As such one of the measures to attract and retain black African women in managerial positions in the workplaces is to provide paid maternity leave to female employees. ${ }^{33}$ This ideal should be welcomed in a civilised democracy and the court has lent its voice to support this, in the case of South African Police Service $v$ Solidarity obo Barnard (CCT 01/14) [2014] ZACC 23 (2 September 2014), the court observed that

"[o]ur quest to achieve equality must occur within the discipline of our
Constitution. Measures that are directed at remedying past discrimination
must be formulated with due care not to invade unduly the dignity of all
concerned. We must remain vigilant that remedial measures under the
Constitution are not an end in themselves. They are not meant to be punitive
nor retaliatory. Their goal is to urge us on towards a more equal and fair
society that hopefully is non-racial, non-sexist and socially inclusive".

More importantly, paid maternity leave is viewed as a progressive step in promoting equality and accords with section $9(3)$ of the Constitution. Significantly, paid maternity leave is desired in South Africa; it is a

\footnotetext{
Schedule Two of the BCEA.

Lues 2005 Interim: Interdisciplinary Journal 103-104.

$S 2$ of the BCEA.

Cabeza and Johnson "Glass Ceiling and Maternity Leave as Important Contributors to the Gender Wage Gap" 2011 Southern Journal of Business and Ethics 73-74.

30 Ss 34 and 37 of the UIA provide for the payment to the employee by the Unemployment Insurance Fund (UIF) of maternity benefits during a period of maternity leave.

31 Boswell and Boswell "Motherhood Deterred: Access to Maternity Benefits in South Africa" 2009 Journal Agenda Empowering Women for Gender Equity 76-78.

32 Booysen "Barriers to Employment Equity Implementation and Retention of Blacks in Management in South Africa" 2007 South African Journal of Labour Relations 47-49.

33 Booysen 2007 South African Journal of Labour Relations 47.

34 Barnard v South African Police Services 2014 (6) SA 123 (CC) par 30.
} 
commendable attribute which all employers should strive for. ${ }^{35}$ In view of ubuntu there is a need for the balancing of interests of the employer and pregnant women in the workplace within the context of promoting effective business and respect for human rights. ${ }^{36}$

\section{THE CONSTITUTION, GENDER, INEQUALITY AND EQUITY}

Since the advent of democracy in 1994, South Africa ensured that its legislative framework enacted through drawing its validity from the Constitution encompasses principles of equality, including gender equality and the empowerment of women. ${ }^{37}$ The Constitution is regarded as one of the progressive Constitutions globally and a beacon for emerging countries (Stevens and Ntlama, 2016). ${ }^{38}$ The South African Constitution provides equal rights and protection to all persons. ${ }^{39}$ Moreover, the State may not unfairly discriminate directly or indirectly against anyone on one or more grounds, including pregnancy and so on. ${ }^{40}$ Discrimination on the ground of pregnancy is unfair unless it is established that the discrimination is fair. ${ }^{41}$ Essentially this means that the employer must prove that the discrimination has taken place, but such discrimination was fair. ${ }^{42}$ This is particularly because the right to equality is subject to the limitation in terms of section 36 of the Constitution.

The importance of the right to equality was articulated by Mohamed DP when he stated in the case of Fraser v Children's Court, Pretoria North 1997 (2) SA 261 (CC) that "there can be no doubt that the guarantee of equality lies at the very heart of the Constitution. It permeates and defines the very ethos upon which the Constitution is premised". According to Mubangi, the right to equality promotes inherently reaffirms that despite the diversity in South Africa, all persons are equal, notwithstanding their status in life. As such, the right to equally aims for a just society. ${ }^{43}$ Essentially, the law must treat all persons equally and this is common law known as formal equality in terms of section $9(1)$ of the Constitution. ${ }^{44}$ However, due to past discriminatory practices, women appear to be the victims of inequality and

35 Ally From Servants to Workers: South African Domestic Workers and the Democratic State (2010) 6-8.

36 The EEA defines a designated employer as an employer who employs 50 or more employees, or an employer who employs fewer than 50 employees, but has a total annual turnover as reflected in Schedule 4 of the Act.

37 Waylen "Women's Mobilization and Gender Outcomes in Transitions to Democracy: The Case of South Africa" 2007 Comparative Political Studies 521.

38 Stevens and Ntlama "Promoting Women's Right to Development in South Africa Law" 2016 Law Democracy \& Development 49.

$39 \mathrm{~S} 9$ of the Constitution.

$40 \mathrm{~S} 9(2)$ of the Constitution.

41 Du Toit "Protection Against Unfair Discrimination in the Workplace: Are the Courts Getting it Right?" 2007 Law, Democracy \& Development 1.

42 Fba "Discrimination Law" (2011) 16.

43 Mubangi The Protection of Human Rights in South Africa: A Legal and Practical Guide (2013) 72.

44 De Waal and Currie The Bill of Rights Handbook (2013) 213. 
as such substantive equality is required for the realisation of their right to equality in South Africa.

Accordingly, the Constitutional Court in the case of President of the Republic of South Africa v Hugo (4) SA 1 (CC)" observed that:

"[w]e need ... to develop a concept of unfair discrimination which recognises that although a society which affords each human being equal treatment on the basis of equal worth and circumstances before that goal is achieved. Each case, therefore, will require a careful and thorough understanding of the impact of the discriminatory action upon the particular people concerned to determine whether its overall impact is one which furthers the constitutional goal of equality or not. A classification which is in one context may not necessarily be unfair in a different context".

Within the workplace the achievement of equity has its genesis to the need for substantive equality in South Africa for women. ${ }^{45}$ Braveman and Gruskin define equity to mean social justice or fairness and assert that it is an ethical concept grounded in principles of distributive justice. ${ }^{46}$ Oosthuizen et al, define employment equity as follows "the employment of individuals in a fair and non-biased manner, thus, to promote equal opportunity by eliminating discrimination in all employment policies and practices". ${ }^{47}$ To this end, women who are discriminated against unfairly in the workplace on the grounds of pregnancy may invoke both the Constitution (s 9), the EEA (s 6) which prohibits unfair discrimination) and section $187(e)$ of the LRA. Generally, discrimination based on pregnancy includes termination of employment, refusal to grant an employee time off, demotion, or being compelled to work in a hazardous environment. ${ }^{48}$

In the case of Wallace $v$ Du Toit [2006] 8 BLLR 757 (LC), an employee was appointed as an au pair to care for her employer's two young children. The woman fell pregnant after a two-year period of her employment and this resulted in the termination of her employment. The employer had not registered the employee to the UIF and as such the woman could not claim any benefits. The employer contends that when the employee was interviewed in late 2001 the question of her starting a family was discussed and he claimed that he made it clear to her that if she had children of her own then he would not regard her as being qualified for the job. The employer expressed that it was a term of the contract, that should the employee fall pregnant, which would inevitably lead to her becoming a mother and having children of her own, then the employment contract would ipso facto terminate. This argument was denied by the employee. The court expressed that it was satisfied that a dismissal as defined in section

45 Akala and Divala "Gender Equity Tensions in South Africa's Post-Apartheid Higher Education: In Defence of Differentiation" 2016 South African Journal of Higher Education 13.

46 Braveman and Gruskin "Defining Equity in Health" 2003 Journal of Epidemiology and Community Health 254.

47 Oosthuizen, Tonelli and Mayer "Subjective Experiences of Employment Equity in South African Organisations" 2019 South African Journal of Human Resource Management/SA 68.

48 McDonald and Dear "Expecting The Worst: Circumstances Surrounding Pregnancy Discrimination At Work And Progress To Formal Redress" 2008 Industrial Relations Journal 229-231. 
186(1)(a) of the LRA had been proven and that the reason for the dismissal related to the employee's pregnancy. The court found that the employer's justification that this was an inherent requirement of the job, and as such cannot in law provide a legal justification. The court emphasised that dismissal where the reason is related to the pregnancy of the employee is automatically unfair and cannot be justified. The employee was awarded damages for the violation of her inherent dignity as a woman and her feelings of hurt she suffered by being dismissed for falling pregnant.

It is observed from this case that the generalisation and stereotyping that fails to consider whether a pregnant employee would be able to continue to fulfil their job function and to simply presume that she could not, when this is not at all self-evident, falls foul of section 6 of the EEA. This form of discrimination further violates the dignity and equality rights in the Constitution. Ubuntu in South Africa denotes respect for human dignity of all persons including pregnant women, In the case of $S v$ Makwanyane 19953 SA 391 (CC) par 225 the court observed that an "outstanding feature" of ubuntu is the value it puts on life and human dignity. It is stated that ubuntu signifies emphatically that "the life of another person is at least as valuable as one's own" and that "respect for the dignity of every person is integral to this concept".

\section{THE LRA AND PROTECTION FROM DISCRIMINATION ON THE GROUNDS OF PREGNANCY}

The LRA provides for the rights and duties of both employers and employees. The LRA provides that dismissal of employees must be both substantively and procedurally fair. This means that a dismissal must be based on a reason of law and that the affected employee must be provided with an opportunity to be heard through a disciplinary process before the dismissal is effected. This is significant because during apartheid, it was an acceptable norm for employers to dismiss female employees at work due to pregnancy. ${ }^{49}$ This form of discrimination has been in the spotlight and still continues post-apartheid era. ${ }^{50}$ It is submitted that termination of a pregnant female is not only automatic dismissal in terms of the LRA but arguably amounts to unfair discrimination in terms of pregnancy, sex and gender espoused in section 9 of the Constitution. In the case of De Beer $v S A$ Export Connection CC t/a Global Paws 2008) 29 ILJ 347 (LC) the applicant (employee) was employed as a travel consultant and fell pregnant. An agreement was entered between the employee and the employer to return to work a month after she had given birth. The female employee gave birth to twins who suffered from colic. Against this background, the employee requested two to three days before returning to work and in addition a further month to look after her twins. The employer was amenable to provide the employee with an extra two weeks. The employee declined this, as such, the employer terminated her services. She then referred a dispute to the CCMA

\footnotetext{
49 Naidoo and Kongolo Has Affirmative Action Reached South African Women (2018) 177 178.

50 Black Sash paper presented at the Black Sash National Conference 1-5.
} 
and contended that her dismissal was automatically unfair in terms of section $187(1)(e)$ of the LRA. The court observed that:

\begin{abstract}
"Section $187(1)(e)$ of the LRA must be seen as part of social legislation passed for the specific protection of women and to put them on an equal footing with men. I have no doubt that it is often a considerable burden to an employer to have to make the necessary arrangements to keep a woman's job open for her while she is absent from work to have a baby, but this is a price that has to be paid as part of the social and legal recognition of the equal status of women in the workplace. If an employer dismisses a woman because she is pregnant and is not prepared to make the arrangements to cover her temporary absence from work the dismissal would be automatically be unfair."
\end{abstract}

It is clear from the above remarks that to level the playing field for pregnant female employees in the workplace, employers must keep the position of a pregnant employee vacant until the employee returns to work. It is submitted that this is part of social justice and recognition that female employees have additional burdens that affect their full participation as employees in the workplace. As such, it is inconceivable for the private sector to dismiss an employee due to pregnancy by citing economic and extra expenses to be incurred by the employer during the absence of the employee. Such a decision will not escape being automatically unfair. ${ }^{51}$ An employee that is dismissed on ground of pregnancy or reasons connected with the exercise of her rights in respect of maternity leave may seek protection in terms of section $187(1)(e)$ of the LRA which grants protection to an employee against dismissal for any reason related to her pregnancy. ${ }^{52}$

Commonly, most of the workplaces, particularly the private sector in South Africa are largely profit-driven and it is submitted that it is conceivable that they deliberately neglect to employ women in general because of the financial implications when they are pregnant. This assertion resonates with the observations of Bosch where it was pointed out that in the workplace most employers encounter challenges once a female employee is pregnant and this includes the relocation of activities that may be harmful to the unborn child, less production and costs for training temporary the replacement. $^{53}$ Similarly, Vettori asserts that a workplace environment must be accommodative of pregnant employees even if it has financial implication to the employer-provided that such cost is not disproportional to the reasonable accommodation. ${ }^{54}$ These challenges have enormous financial implications for employers. Notwithstanding this, financial implications cannot be a justification for the discrimination of pregnant employees in the

51 Barnard and Rapp "The Impact of the Pregnancy Discrimination Act on the Workplace From a Legal and Social Perspective" 2005 University of Memphis Law Review 93.

$52 \mathrm{~S} 187(1)(e)$ of the LRA provides: "A dismissal is automatically unfair if the employer, in dismissing the employee, acts contrary to section 5 or, if the reason for the dismissal is the employee's pregnancy, intended pregnancy, or any reason related to her pregnancy."

53 Bosch "Pregnancy Is Here to Stay - Or Is It?" in Bosch (ed) SABPP Women's Report (2016) 3-6.

54 Vettori "Employer Duties Towards Pregnant and Lactating Employees in the Hospitality Industry In South Africa" 2016 African Journal of Hospitality, Tourism and Leisure 12. 
workplace. ${ }^{55}$ As part of its internal obligations under Convention on the Elimination of All Forms of Discrimination Against Women, human rights treaty adopted by the General Assembly of the United Nations in 1979 (CEDAW) that defines discrimination against women and commits signatory countries to taking steps toward ending it. Article 11 of CEDAW requires South Africa to take steps to eliminate discrimination against women in the workplace to achieve equality between men and females in terms of rights and remuneration. The discrimination of pregnant women is further prohibited in terms of article 11(2)(a), instead article 11(2)(b) advocates for maternity leave with pay, or with comparable social benefits without loss of former employment, seniority, or social allowances.

The significance of article 11 of CEDAW is that it laments the equality and dignity of women in the workplace. Importantly, article 11 of CEDAW is relevant in addressing the historical; and patriarchal attributes that view women as inferior beings and consequently not entitled to work. Article 11 provides women with the right to work and also provides women with equal opportunities in the workplace and equal remuneration for work of equal value. In other words, women and men who are executing the same duties in the same positions in the workplace must be remunerated equally.

South Africa signed and ratified CEDAW in 1995. This resulted in South Africa being a State Party to CEDAW and therefore voluntarily accepting to a range of legally binding obligations to eliminate discrimination against women in all spheres including, employment. By doing this, South Africa agrees to comply with the norms and standards collectively agreed to by State Parties and further agree to be subjected to scrutiny by the CEDAW committee.$^{56}$ The basic State obligations under article 2 of CEDAW include inter alia the following:

- To promote equality of men and women in the legal systems by abolishing discriminatory laws against women.

- To put in place public institutions to hold the State and private companies accountable by ensuring the effective protection of women against any act of discrimination.

- To eliminate any act or practice that discriminates against women.

Essentially article 2 charges State Parties to adopt the egalitarianism process that will eliminate direct and indirect discrimination against women. These processes include the adoption of laws that promote nondiscrimination of women, the establishment of independent bodies that investigates discriminatory practices of the State and an effective justice system that can be used to compel the State not to discriminate unfairly against women.

55 Barnard and Rapp "Pregnant Employees, Working Mothers and the Workplace Legislation, Social Change and Where We Are Today" 2009 Journal of Law and Health. 218-220.

56 The CEDAW Committee has been established to monitor State Parties compliance of the recommendations issued by CEDAW. 


\section{THE RIGHT TO MATERNITY LEAVE AND BREASTFEEDING FACILITIES IN THE WORKPLACE}

The right to maternal leave is recognised internationally through the Maternity Protection Convention, 2000 (MPC 2000) which was adopted on 15 June 2000. The MPC recognises the importance of promoting equality of all women in the workplace and health and safety of the mother and child. In terms of article 4 of the MPC 2000, women are entitled to a period of maternity leave of not less than 14 weeks. State members are however encouraged to extend maternity leave to at least 18 weeks. Article 6 of MPC 2000 states that cash benefits shall be provided to women who are absent from work due to maternity leave. Article 8 of MPC 2000 bars employers from terminating employment of a pregnant employee during pregnancy or absence of maternity leave or her return to work. Article 8 of MPC 2000 provides that a woman is guaranteed the right to return to the same position or an equivalent position paid at the same rate at the end of her maternity.

Article 9 of the MPC 2000 states that Member States need to adopt appropriate measures to ensure that maternity does not constitute a source of discrimination in employment, including access to employment. Article 10 of the MPC 2000 provides that a woman shall be provided with the right to one or more daily breaks or a daily reduction of hours of works to breastfeed her child. Article 10 of the MPC 2000 denotes that the nursing or breastfeeding or reduction of daily hours of work shall be counted as working time and remunerated accordingly.

The MPC recognises the importance of giving protection to female employees who are pregnant at work. It is argued that the MPC assists in ensuring that women continue to contribute to a country's economic growth without being marginalised in the labour market due to pregnancy. It is accepted that the marginalisation of pregnant women in the workplace deprives women of choice and opportunities in employment and is essentially contrary to the normative considerations of fairness and justice. ${ }^{57}$

In 2010, the International Labour Organisation (ILO) found that the maternity leaves in South Africa ranked the highest in Africa. In South Africa, pregnant women are provided with four consecutive months' maternity leave. This is in accordance with section 25 of the BCEA. Section 25(4) of the BCEA provides further protection to pregnant employees by barring employees from working for six weeks after the birth of a child unless a medical practitioner or midwife certifies that she is fit to do so. Similarly, an employee who has experienced a miscarriage on their third trimester of pregnancy or bears a stillborn child has a right to maternity leave for a period of six weeks after the miscarriage or stillbirth, whether or not the employee had commenced maternity leave at the time of the miscarriage or stillbirth. ${ }^{58}$

\footnotetext{
57 International Labour Organisation (ILO) Maternity Protection Resource Package, Maternity Protection at Work: Why is it important? (2012) 4.

58 S 25(4) of the BCEA.
} 
Through the BCEA employers are challenged to proactively provide an alternative employment to a pregnant employee on the terms and conditions that are no less favourable than her ordinary terms and conditions of employment. The reading of the BCEA informs the view that the intention of the legislature when drafting the BCEA was to cater inter alia for the needs of female employees by ensuring that their jobs are safeguarded even during and after pregnancy. According to Klerman and Leibowitz "maternityleave promise advantages for both infants and their mothers. Infants are expected to benefit from their mother's full-time care during the maternityleave guarantee period. The mothers benefit not only from increased time to spend with their new-borns but also from the right to return to their jobs without penalty." ${ }^{59}$ As such, employers must guard against discriminating against pregnant employees in the quest to achieve profit and efficiency of the business. ${ }^{60}$ Employers are bound by the legal prescripts to ensure that human rights, ubuntu and non-discrimination of pregnant employees are promoted in the running of the business. For a fair discrimination, the employer must rely on the inherent requirement of a job and such requirement must be so inherent that if not met the employee would not qualify for the position. ${ }^{61}$ It was decided in the matter of Woolworths $v$ Whitehead (CA06/99) [2000] ZALAC 4 (3 April 2000) that a party who claims discrimination, must show that but for her pregnancy, she would have been appointed. In other words, there must be a causal connection between her not being appointed to a position and her pregnancy.

In the case of Woolworths $v$ Whitehead, Ms Whitehead (Respondent) had applied for a senior human resources position at Woolworths (Appellant). The respondent contended that, based on her pregnancy, the appellant withdrew the permanent employment offer and offered temporary employment for five months, which would essentially have endured until she commenced her maternity leave. The appellant concedes the respondent was discriminated however argues that the discrimination related to the requirement of uninterrupted job continuity which requirement applied equally to any applicant for the position advertised; and further the job continuity need not be interrupted for at least twelve months and was rationally and commercially supportable. ${ }^{62}$ The court observed that:

"A careful balancing of interests is required in a case such as this. We live in a country with pervasive poverty, poor social security, high unemployment and a low growth rate. Without a rapidly expanding economy, it will be impossible to deliver to our society so many of the changes and improvements it so desperately needs. At this stage of our history, to hold that an employer cannot take into account a prospective employee's pregnancy would be widely regarded as being so economically irrational as to be fundamentally harmful to our society.

Notwithstanding the progressive legal framework that guarantees basic conditions of employment, the lack of compulsory paid leave arguably adds

\footnotetext{
Klerman and Leibowitz "Job Continuity Among New Mothers" 1999 Demography 145-147. Whitehead v Woolworths (C 122/98) [1999] ZALC 82 (28 May 1999) par 32.

Whitehead $v$ Woolworths supra par 37.

Woolworths (Pty) Ltd $v$ Whitehead (CA06/99) [2000] ZALAC 4 (3 April 2000) par 46.

Woolworths (Pty) Ltd $v$ Whitehead supra par 136.
} 
a financial burden to pregnant employees. In the case of Manetsa $v$ New Kleinfontein Gold Mine [2018] 1 BLLR 52 (LC) paragraph 4, the court held that "it can further not be doubted that whilst on maternity leave, whether paid or unpaid, pregnant employees by virtue of their absence from the workplace in certain instances invariably lose out on advantages of being at the workplace, such as bonuses, promotions, and career development in the form of training and development offered to other employees". ${ }^{64}$ The court correctly further pointed out that:

\begin{abstract}
"[p]regnant women continue to worry about the prospects of their continued employment once they disclose their pregnancy or even after childbirth ... workplaces that provide child care facilities. These problems cut across all industries but are even more prevalent in sectors of our economy that are traditionally male-dominated such as mining ... Female employees become unintended casualties of their pregnancies or womanhood".
\end{abstract}

These remarks inform the view that pregnancy has the effect of denying women of opportunities that can be of assistance in their progression and advancement in the workplace especially in predominately male-dominated sectors. This resonates with the findings of the National Research Council that unearthed that motherhood is a major reason that companies promote fewer women compared to their male counterparts. ${ }^{66}$ The National Research Council report of 1994 unearthed further that women with children are often not promoted at companies and this has resulted in other women hiding their pregnancies. ${ }^{67}$ Interestingly, the Commission for Gender Equality (CGE) report (2018) has observed that most private sector companies do not have childcare facilities in the workplace, do not offer breastfeeding breaks in the workplace nor offer paid maternity leave. ${ }^{68}$ It is submitted that an employer that fails to introduce in a workplace an environment that is sensitive to the needs of women, will unlikely not attract potential female employees and would similarly not retain its female employees. Of course, the employer would not be able to attract and retain skilled women who would add value to the company.

The workplace needs to transform and progressively create an enabling environment that is sensitive and accommodative to the needs of female employees and pregnant employees in general. ${ }^{69}$ To achieve this, the BCEA provides guidance through a Code of Good Practice on the Protection of Employees during Pregnancy and After the Birth of a Child (the Code of Good practice). The Code of Good Practice protects female employees to return to work while breastfeeding and states that a nursing mother may breastfeed 30 minutes twice a day at the workplace. The Code of Good

Manetsa v New Kleinfontein Gold Mine [2018] 1 BLLR 52 (LC).

65 Manetsa $v$ New Kleinfontein Gold Mine supra par 4.

66 National Research Council (NRC) Women Scientists and Engineers Employed In Industry: Why So Few, 1994 (1996) 41.

67 National Research Council Women Scientists and Engineers Employed In Industry: Why So Few, 199442.

68 Commission for Gender Equality (CGE) Employment Equity Hearings in the Private Sector (2018) 52-58.

69 Major Pregnancy in the Workplace: Stigmatization and Work Identity Management Among Pregnant Employees (Psychology Theses and Dissertations UMD Theses and Dissertations) 2004 1-6. 
Practice further requires the employers to assess and control risks to the health and safety of pregnant and breastfeeding mother in the workplace.

To this effect, the Code of the Good Practice prescribes that "arrangements should be made for pregnant and breastfeeding employees to have breaks of 30 minutes twice a day for breastfeeding or expressing milk each working day for the first six months of the child's life". ${ }^{70}$ For the breastfeeding breaks to benefit employees, it is conceivable that employers provide child care facilities in the workplace alternatively provide flexibleworking hours to women who are still breastfeeding.

It is submitted that the existence of child care facilities in the workplace will assist women in balancing their work role and family responsibilities. The CGE unearthed that most companies in South Africa do not provide child care facilities in the workplace. ${ }^{71}$ Conversely, Doubell and Struwig postulate that child care responsibilities associated with school-going children did not support the narrative that this is a barrier to women's career success. ${ }^{72}$ It is submitted that a workplace that provides breastfeeding breaks and facilities would be viewed as an enticement and has the effect of attracting black African women to join the private sector and not leave to other sectors. ${ }^{73}$ This is against the backdrop understanding that most employers do not provide opportunities for women to breastfeed at work. ${ }^{74}$ Commonly, the job may be demanding in nature and required extra effort, and generally requires more hours at work. To this end, in order to ensure that women are on an equal footing with their male counterparts, breastfeeding facilities are imperative in the workplace. ${ }^{75}$ The establishment of breastfeeding facilities would essentially assist women to have a work-life balance. ${ }^{76}$

Remarkably, Bidvest was one of the companies that appeared before the CGE and was found to have had an in-house crèche facility available to its employees which was an attractive measure to entice women to join the company. ${ }^{77}$

According to UN Women, when a company introduces child care facilities in the workplace it has the effect of improving punctuality, reduces absenteeism and further increases productivity and motivation for women. ${ }^{78}$

70 Code of Good Practice on the Protection of Employees during Pregnancy and After the Birth of a Child, 13 November 1998, s 5.13.

71 CGE Employment Equity Hearings in the Private Sector 39.

72 Doubell and Struwig "Perceptions Of Factors Influencing The Career Success Of Professional And Business Women In South Africa" 2014 South African Journal of Economic and Management Sciences 532.

73 Groenmeyer Women And Social Policy-Experiences Of Some Black Working Women In Contemporary Post-Apartheid South Africa (PhD thesis, Department of Sociology and Political Science, Faculty of Social Sciences and Technology Management, Norwegian University of Science and Technology, NTNU, Trondheim) 2011 1-4.

74 Netshandama "Breastfeeding Practices Of Working Women" 2002 Curationis 21.

75 Salcedo "Breastfeeding in the Philippine Workplace: What's Wrong with the Right?" 2015 DLSU Business \& Economics Review 124.

76 Salcedo 2015 DLSU Business \& Economics Review 124.

77 CGE National Employment Equity Report (2010-2011) 15.

78 International Finance Corporation, Tackling Childcare (IFCTC) "The Business Case For Employer-Supported Child Care" (2017) www.ifc.org/wps/wcm/connect/topics_ext 
Lack of child care facilities is recognised as a barrier to female labour force participation. It is from this premise that the CGE recommended that the workplace must have child care facilities to enable females to balance their roles as employees and their roles as mothers and/or primary caregivers. ${ }^{79}$ This recommendation is based on soft law and is not legislated but it is desirable.

\section{CONCLUSION}

What is remarkable from the submissions above is that all the transformative interventions discussed require that pregnant employees be treated comparably with others on the basis of ability or inability to work. Women continue to be discriminated in the workplace on various grounds and on the grounds of pregnancy and breastfeeding. Procreation and bearing a child are parts of an inherent and inalienable endowment for women from the time immemorial, and this shall continue. Women who are pregnant should not be discriminated at all in the workplace rather they should be given all the supports they need. Regrettably, apartheid South Africa denied women, particularly black African women all these rights with impunity. Postapartheid 1994, women rights have been restored and given to them starting from the Constitution which expressly provides for the respect of human dignity and human rights where all, men and women are considered as equal in all aspects and respects irrespective of their gender. The Constitution promotes and protects equality and frowns against inequality of any types. Therefore, women's rights to work, be pregnant and bear children are duly protected. Similarly, protective transformative pieces of legislation and policy have been introducing and being implemented to guarantee women right generally and in the workplace. The LRA expressly provides for unfair labour practices hence dismissal or discrimination on the ground of pregnancy will be unfair labour practice and the court will not hesitate to reinstate the dismissed employee. Similarly, international instruments particularly CEDAW abhors discrimination against women and promotes the right of women to be pregnant. The private sector employers are notorious from discriminating against pregnant women. The good news is that there are ample transformative interventions like the EEA, BCEA, LRA and the Code that are available to pregnant women to seek redress against erring employers at the appropriate court. As part of protective mechanisms to ensure that the right of pregnant women are guaranteed prior and after pregnancy even at birth in the workplace, maternity leave, breastfeeding and crèche facilities are imperatives for a nursing mother to continue to discharge her responsibility to the employer. 